\title{
Optimization Strategy for Handling Poverty towards Strengthening the Economy in Indonesia
}

\author{
Ansar / Patta Rapanna \\ (Lecturer Of Stim Yapim Maros /Lecturer Stiem Bongaya, Makassar, South Sulawesi)
}

\begin{abstract}
This type of research is a qualitative phenomenological approach through, the results showed that the Government in providing public services in terms of the handling of poverty, requires an optimal strategy, and focus to the public as the object and subject of development, this can be done via the same cooperation between agencies and the flagship strategy i.e. family Program Expectations; community empowerment - among other things through the national community empowerment Program Independently, here the community is empowered to correct fate independently, ranging from building roads, irrigation, up to the establishment of the mechanism of granting revolving capital; the grant program and the expansion of people's access to business credit, fulfillment of fundamental activities.
\end{abstract}

Keywords: strategy, poverty, economy, optimizing, strengthening.

\section{INTRODUCTION}

\section{A. Background}

Nowadays the people who enter into the people who should be empowered often identified with people who live under the poverty line. Because in accordance with the reality of life there, the people who live under the poverty line and it will be directly proportional to the level of welfare of her low so with such circumstances, poor people do not have access or a great opportunity to be able to obtain all the resources to develop their potential

It increasingly emphasized in Act No. 25 of 2000 year Propenas which mentioned that poverty is a problem of development characterized by unemployment, underdevelopment, and deterioration. Poor weak in ability of trying and had restricted access to the socio-economic activities. To tackle the problems that then must be done a way that is to be done through community empowerment program of poverty reduction.

However, not all programs running in line or poverty reduction in accordance with the concept of community empowerment. Due to community empowerment is an efforts planning designed to change or do the upkeep on a community or society from the condition of helplessness became helpless with emphasis on self-reliance and potential coaching community.

Poverty is a social phenomenon that is not only experienced by countries that are developing but also occurs in a country that already has the ability in the field of economics. This phenomenon is basically has become a concern, issues, and global movement that is humanity.

The problem of poverty itself has indeed been long in existence since ancient times. In the recent past generally being poor society not because of lack of food, but the poor in the form of lack of material. Of the size of modern life on the present they do not enjoy facilities of education, healthcare, and other amenity available on the modern era. The problem of poverty facing the country will always coincide with the issue of rate of population growth which then generate unemployment, inequality in the distribution of national income or development, and education became the main capital to be able to compete in the workforce today.

In the Decade of the 1976-1996, the percentage of the poor population in Indonesia ever experienced a decrease of $40.1 \%$ to $11.3 \%$, yet in the period 19961998 this figure be $24.29 \%$ or 49.5 million. Even the International Labor Organization (ILO) estimates the number of poor people in Indonesia reached 129.6 million or approximately $66.3 \%$ (BPS, 1999). In 2002 , the percentage of poverty has decreased, but in absolute terms the number of those still classified as high, i.e. $43 \%$ or approximately 15.6 million (BPS and Depsos 2002). Just imagine, if the year 2002 only poverty of $43 \%$ and then what about the year 2010 . of course. Certainly the sja poverty levels by the year 2010 the higher views of birth rates especially in Java. Without prejudice to the meaning of the importance of development that had already been made, poverty indicates the concept model to be built has not yet been able to form a formidable community socioeconomic.

The problem of poverty is a complex problem and multidimensional in nature, therefore, poverty reduction efforts must be conducted in a comprehensive manner, covering various aspects of 
people's lives, and implemented integrated Nasir (Prastyo (2010). In poverty reduction efforts there are two main strategies that should be pursued by the Government. First, protect the poor families and groups through the fulfillment of their basic necessities. Second, it empowers them to have the ability to do business and to prevent the occurrence of new poverty.

The underlying factors that cause poverty include: HR, SDA, system, and is also inseparable from the figure of the leaders, so that the very dimension has to do with one another. to date the poverty in Indonesia is still the homework that has to be dealt with absolute, professional and finding the root problems of poverty.

\section{Formulation of The Problem}

How do the optimization strategy of handling of poverty in Indonesia

\section{Research Objectives}

To know the optimization strategy of handling of poverty in Indonesia

\section{A REVIEW of THE LITERATURE \\ A. Poverty}

Hall and Midgley (2004:14), stating that poverty was defined as the condition can be a material and social deprivation which causes the individual to live under a decent life standards, or the conditions under which the individual is experiencing relative deprivation compared with other individuals in society. John Friedman, poverty was defined u.s. inequality of opportunity to accumulate social power base. Social power base include (not limited to) a productive capital or assets (such as land, housing, equipment, health, and other) sources of finance, social organization and political can be used to achieve common interests, social networking to get a job, the goods; adequate knowledge, skills and useful information (Richard Quinney,. 1979).

Arun (2007), shared a way of thinking that view poverty as absolute symptoms; and, as a relative symptom. How to think (model) about poverty as a symptom of absolute poverty as the condition looked versatile material deprivation, have little or even do not have the means to support a life of its own. How relativistic point of view consists of two viewpoints, that of viewpoints (model) culture, and how structural standpoint (model). Then, beginning in the 1990 s, there was a new development in the approach towards poverty, i.e. look at poverty as a process. Approach of process on poverty have just known in Indonesia. For the most part, the approach used in the scientific as well as practical space still dominated the cultural and structural approach as discussed above.
According to James c. Scott is quoted in the writings of Gregory Sahdan in saying that; In a country that is mismanaged, there is no greater issue, other than the question of poverty. Poverty has made millions of children could not be pursuing a quality education, the difficulties of financing health care, lack of savings and the lack of investment, lack of access to public services, lack of jobs, lack of social security and protection for the family, the rise of urbanization to the city, and a more severe poverty, causing millions of people to meet the needs of food, clothing and boards are limited. Poverty, causing the villagers willing to sacrifice anything for the sake of survival, safety of life (James c. Scott, 1981).

\section{B. Empowerment}

Sunyoto Usman (2003) revealed that the construction was done by a country at this time will not be able to escape from the influence of globalization that swept the world. The question of politics and economics can no longer simply be viewed as a national issue. Linkages between countries becomes a question that deserves to be taken into account. Economic or political problem faced by a single country swept up in other countries to bring and that problem will evolve into an international problem.

According to Soejadi (2001), poverty is one of the issues that always faced by humans. Poverty can be defined as a low level of living standard, i.e. There is a level of lack of material or a party to a number of people as compared with the standards in force in the public life of the community is concerned. This low life standards directly affect State-level look health, moral life, and sense of self-worth of those classified as poor. In developing countries, the discourse of empowerment comes when construction raises social issues, economic inequality, degradation of natural resources, and the community's alienation of factors of production by the ruler (Prijono, 1996).

According to John Friedman (1991), empowerment can be defined as the acquisition of power and access to resources for a living. Even in a political science perspective, the strength of the concerns on the ability to influence others.

\section{Economic Development}

Economic development cannot be simply interpreted the U.S. with growth or industrialization. Economic development means growth coupled with the changes (growth plus change), because of the qualitative dimensions are quite important in the development process. Realize that in the process of construction of the often occurring impact of the unwanted by the public, such as the gap in the distribution of income, inequality and poverty. 
Meier mentions the US economic development, ... the process whereby the real per capita income of a country increases over a long period of time - subject to the stipulations that the number below an absolute ' poverty line does not increase, and that the distribution of income does not become more unequal (Meier, 1984:6). From this definition it can be concluded that the indicator of the success of an economic development is growth, the existence of equitable and improved welfare society (PEP-LIPI, 2001).

Sukirno (1985) stated that economic development is a process that caused per capita income of residents of something the community increased in the long run. On the basis of this definition, economic development is: (i) a process, which means it is the changes that occur continuously, (ii) attempt to raise the per-capita income level, and (iii) the increase in per capita income was to be continued in the long term (Prayitno, H and Budi Santoso, 1996).

Thus, development must be seen as a multidimensional process that includes a variety of fundamental changes over the social structure, the attitudes of society, and national institutions, besides the permanent pursuit of accelerated economic growth, income inequality and handling, as well as poverty reduction. So in fact, that the construction of the need to reflect the changes of a society or a total adjustment of the overall social in system, without ignoring the diversity of basic needs and wants of the individual as well as social groups is in it, to move forward toward a condition better all-round life, materially as well as spiritually (Todaro, 2004).

The accumulation of human capital has long been regarded as an important factor of economic development. The results obtained in the initial set of Regression By because it was a bit disappointing when someone runs the specifications implied CobbDouglas in Jess and Mark (1994) is function of standard production which include human capital as a factor of the human capital accumulation, which failed to enter significantly in the determination of the growth of the economy, and even came in with a negative point estimate.

More and better education is a prerequisite for economic development by leaps and bounds in all over the world. Education stimulates economic growth and improve people's lives through many channels: by increasing the efficient use of labor force, by increasing democracy (Barro, 1997 in Thorvaldur, 2001) and thus create better conditions of good governance, through improved health, by increasing the equality (Aghion et al., 1999 in Thorvaldur, 2001).
Example, or a model, a successful theory is a theory of economic growth Robert Solow and Edward Denison (Robert, 1988) was developed and applied to the U.S. experience of the twentieth century. This theory would serve as a basis for further discussion in three ways: as an example of a form that agregatif theory useful should take, as a chance to explain what theory this form can tell us that other types of theory cannot, and as probability theory to economic development.

\section{Public Policy}

Public policy is the collective action that is realized through a legitimate Government authority to encourage, inhibit, prohibit or regulate the actions of private (individuals or private institutions). Public policy has two principal characteristics. The first, made or processed by government institutions or based on the procedure established by the Government (Hogwood and Gunn, 1988 in Simatupang, 2011). Second, the nature of the force or effect on private actions the public (public). For example, the fuel price policy is a public policy because it is made by the Government are forcing and can have an effect on the economic life of the inhabitants, the consumer as well as entrepreneur.

Public policy is what is selected by the Government to be done or not done. Carl Friedrich in Mariana (2010) sets forth that the policy is potentially experiencing unplanned actions or activities proposed by a person, group, or Government in an environment where there is a certain obstacles (difficulties) and the possibilities (opportunities) where the policy is proposed in order to be useful in addressing it to achieve the objectives in question.

Public policy is a relatively new science because historically emerging in the middle of the Decade 1960 's as a discipline that stands out in the sphere of public administration as well as political science. In the meantime, analysis of public policy could arguably have long existed and can be traced the existence of human civilization. Since then, public policy is inseparable from the human life in the form of individual or micro-level context of macro level in the life of society and State (Wahab Bakry, in 2008, 2010).

Aware public policy sense variations so vast and inevitable, because term policies attempt to explain in brief the various actions ranging from observing the issue or problem, formulate the formulation and monitoring and evaluation. This article refers to the notion that any legislation and regulations is the policy, but not every policy is manifested in the form of legislation or regulation. In the context of the notion of public policy such as these, identified dimensions that are interlocked 
between public policy as the legal action is a legal choice, public policy hypotheses and public policy as a destination (Bridgeman and Davis, 2004 Bakry in 2010).

\section{B. Public Service}

The concept of a public service by the Government are serving, trial, and cultivate the initiative and an active role in community development. Government services are given at every level of Government both at the Central Government, regions or villages. The concept of a public service that is conducted by a Government described by Munir (2002) in Kuswandi (2005) that: service to the community in General is defined as public service or the public service. IE as an activity undertaken by a person or a group of people with a grounding system through material factors, specific methods and procedures, in order to meet the business interests of another person in accordance with its rights.

In terms of execution of the service is done by the Government, further Munir (2002) (Kuswandi, 2005) explains that there are several factors to look for in supporting a service IE: consciousness of officials as well as officers who are engaged in service, the rules that became the cornerstone of the work of the Ministry, organization which is a tool as well as a system that allows the passage of the revenue service, mechanisms that can meet the minimum necessities of life, giver of Ministry officers skills and means in the implementation of the tasks of the Ministry.

\section{Research Methods}

This type of research is a qualitative Phenomenological approach through

\section{Discussion}

1. Optimization of the handling of poverty in Indonesia

\section{A. The Problem and the Proper Handling of Poverty}

The economic crisis in $1998 \mathrm{t}$ gives the lacing to the national economy, including increasing poverty communities that rose to 49.50 Million or about $24.23 \%$ of the population of Indonesia, from only 34.01 million $(17.47 \%)$ in 1996 . To reduce poverty due to the economic crisis, the Government then set poverty reduction efforts as one of the priorities of the Government of Indonesia.

Program execution countermeasures poverty undertaken since 1998 to date, generally capable of lowering the poverty figures for Indonesia which amounted to 47.97 Million or about $23.43 \%$ in 1999 be 30.02 Million or around at $12 \%$ in 2011. Based on the World fact book, BPS, and the World Bank, at the level of the world's poor population decreased in
Indonesia including the fastest compared to other countries. Recorded on the range of years 2005 to 2009 Indonesia is capable of lowering the average rate of decline in the number of poor population per year amounted to $0.8 \%$, far higher than the achievement of other countries such as Cambodia, Thailand, China, and Brazil that just being in the range of $0.1 \%$ per year.

The current Government has the various integrated poverty reduction programs ranging from poverty reduction program based on social assistance, poverty reduction programs based community empowerment as well as

To improve the effectiveness of poverty reduction efforts, presidential Regulation (Regulation) No. 15 of 2010 about Accelerating poverty reduction, which aims to accelerate the decline in poverty up to $8 \%$ to $10 \%$ by the end of 2014.

There are four basic strategies that have been assigned to do the acceleration of poverty reduction, namely:

- Perfecting social protection program

- increased access of the poor against the basic services

- Empowerment of the community, and

- an inclusive Development

Associated with the above strategy, the Government had established a poverty reduction instruments is divided on the basis of the three working groups, respectively:

- Working Group (Pokja) social assistance Policy

- Working Group (Pokja) Health Guarantee Policy

- Working Group (Pokja) Policy of increased economic capacity \& Income

When referring to the poverty Indicators according to Bappenas (2006) is a restriction on the adequacy and quality of food, the limited access and low quality of health services, the limited access to quality services and low education, limited job opportunities and trying, with limited access to housing and sanitation services, the limited access to clean water, to weak certainty of ownership and control of land, worsening the condition of environment and natural resources, weak collateral security, weak participation, and the magnitude of the burden of population caused by the magnitude of family dependents and pressure of life that encourages the occurrence of migration. The limitations of the adequacy and quality of food as seen from the limited food stocks, the low caloric intake of the population poor and poor nutritional status of infants, toddlers, children and mothers. About 20 percent of the population with the lowest income level just consumes 1,571 kcal per day. Shortage of caloric intake, i.e., less than 2,100 kcal 
per day, still experienced by 60 per cent of the lowest income earners (BPS, 2004). Cases concerning malnutrition this year increased quite significantly, in 2005 recorded 1.8 million sufferers of childhood malnutrition, and in October 2006 are recorded 2.3 million children suffering from malnutrition.

Limitations of access and the low quality of health services caused by the difficulty of getting basic health services, poor quality of basic health services, lack of understanding of the behavior of healthy living, and the lack of reproductive health services, the health service facilities, maintenance costs and an expensive treatment. On the other hand, hospital utilization is still dominated by the able, while the poor are likely to avail of services at the clinic. Likewise the delivery assisted by health workers, on the poor population only amounted to $39.1 \%$ compared to $82.3 \%$ in the population of the rich. Health insurance as a form of social security system only reach $18.74 \%$ of the population, and only a fraction of which the poor population (BPS, 2001).

Limitations of access and the low quality of education services are indicated by gaps in education costs, education facilities are limited, the cost of an expensive education, the chance of obtaining a limited education, the high burden of tuition fees either direct or indirect costs. Limitations of employment opportunities and seek also indicated weak protection against the assets of the business, and wage differences and the weak protection of work especially for the child workers and women workers, such as women and migrant workers ' household helpers. Limitations on access to housing and sanitation services demonstrated the difficulties faced by poor communities living in the area of fishing, farming, and forest fringes of dry land in obtaining housing and environment healthy and viable settlement. In one House is often found more than one families with sanitation facilities are inadequate.

Weak community participation is shown with various cases of eviction urban, termination of employment unilaterally, and the expulsion of the farmers of arable lands. The low participation of the poor in the formulation of policy is also caused by a lack of good information about the policies to be formulated nor the mechanism which allows the formulation of their involvement. Judging from the magnitude of the burden of population caused by the magnitude of family dependents and pressure of life that encourages the occurrence of migration, according to BPS data, poor households have family members on average larger than households not poor. Poor households in urban areas have average members 5.1 a person, while the average poor household members in the countryside is 4.8 persons.

Publications of the World Bank (2001) contains a comprehensive discussion about the agenda of poverty reduction in Indonesia. One of the themes put forward is the need to broaden the definition, facts, and the purpose of the anti-poverty program. In addition to the praise that until the crisis with Indonesia 1997-1998 able to achieve spectacular results in reducing the number of poor population, the World Bank also gave criticism that the approach applied to poverty reduction in Indonesia - too focuses on a target figure. The poverty line for example, emphasized on expenditure to meet the needs of life in a very narrow sense. The target figures combined with a development approach that is both top-down has put aside many of the dimensions of poverty - which although difficult to measure, but it is very important. By just looking at the statistically they fall into the category below the poverty line, this approach narrowed its scope of poverty and the poor reality distanced from the more dynamic.

Ignore the numbers and keep away from mathematical target certainly is also unlikely, because however figures remained necessary. On the other hand, focuses on the achievement of targets too stats also don't thoughtful due to too simplify the problem. The World Bank and then recommends the use of international development indicator compiled by the representative of the international community - including Indonesia and one of its members. The expansion of poverty reduction targets as recommended by the World Bank is more focused on the depth of the target that has been set for this. On the dimensions of a standard of life materially for example, the proportion of the poor population of the year 1999 was $27 \%$, so that the likelihood of the target in 2004 is $13.5 \%$. On the human resources dimension can also developed target numbers for example, completed primary education in the poorest population groups, the level of infant mortality as well as health level. Similarly, access to infrastructure, the poorest group whether access against the water resources or sanitation can be upgraded five years. Increased participation among the poor population in the local political decisions that affect their lives, through certain programs, it is no less important.

During the period of 1975-1995 Indonesia has been successful in reducing poverty is primarily measured through a decrease in the number of poor population from $64.3 \%$ in 1975 to only $11.4 \%$ in 1995. In the same year Age life expectancy has increased from 63.7 to 47.9 years, infant mortality per thousand births can be pressed from 118 be 51 
primary school participation rate increased from 75.6 be 95 , and high school participation rates also increased from $55 \%$ being 13 .

\section{B. Empowerment of Small Medium Enterprises}

Of the several problems of empowerment of small medium enterprises above, central government encouraged the program how can move small medium enterprises sector. Among them is by seeking the granting of financing software on this sector. Related programs this is such a guarantee program and channeling people's business credits (kur). The development of cooperatives and small enterprises micro and medium is the most appropriate way and quickly to tackle poverty and unemployment as well as to improve the people's welfare. This is because the program channeling credit to cooperatives and small medium enterprises guarantee pattern will resolve the problem so far, namely the difficulty of small medium enterprises and cooperative sector gets credit from banking.

The realization of the people's business credit or savior since its launch president Susilo Bambang Yudhoyono on November 5, 2007 continues to show improvement. Even as late as march 2008 credit it already reached rp 3.276 trillion with the amount the debtor 187,860 micro-entrepreneurs and small

From the program (kur), small medium enterprises sector can be expected to grow and develop in supporting the nation's economy. In addition, through this program, the government is also targeting small medium enterprises sector can grow by 650,000 small medium enterprises unit.

In addition to the program, the government is also preparing kur program in poverty reduction in Indonesia. Of course the program also will synergize with the empowerment of small medium enterprises sector. This program is called the national community empowerment Program or better known by the acronym PNPM.

The existence of micro enterprises, is the fact the spirit of true entrepreneurship among the souls of the people who get to be the pioneer of renewal. Aware of this reality, focusing mainly on people's economic development micro enterprises is very strategic to realize broad based development or development through equity. In addition to accommodate Equalization as mentioned above, develop a business group is the real strategic views, at least some of the reasons are: 1) they have productive economic activities so that their needs are development and capacity building - not established, making it more convenient and definitely; 2) if the group is appropriately empowered, they will easily move into the small business sector; 3) effectively alleviate poverty suffered by their own, or help the poor handling of the category of the poor, as well as the elderly and young.

See the role of micro enterprises this strategic question, why the business is most difficult to develop. For micro-entrepreneurs, the question of the capital - accessibility to capital turns out to be is a problem. The lower layers of society in General barely touched - undeserved and not considered to have the potential funds by formal financial institutions, causing the rate of economic development hampered at the level of subsistence only. These community groups judged not worthy of the bank - not because it has no bankable collateral, as well as restoring his abilities assumed low saving habits, low, and high transaction costs. Due to that assumption, then the accessibility of microentrepreneurs towards formal financial sources is low, so most of them rely on capital as they have. One way to solve the thorny problems that, namely the financing of poor micro-entrepreneurs, is through microfinance. In Indonesia itself it's not the new stuff. Bank Rakyat Indonesia which was established 100 years ago also leads like that. In the sphere of the world, microcredit approach gained momentum recently, namely the existence of the Microcredit Summit held in Washington dated March 1997 2-4. MS is a sign of the beginning of the global movement of community empowerment with the strengthening of the Fund to the community based on the experience of many countries. MS also gives some kind of a new spirit because MS doesn't just display the keragaan success of microfinance activities in empowering communities - the people's economy, but also a mematrikan together to tackle global poverty by as much as 100 million families - or about 600 million people. Microfinance serves to support capital for micro-entrepreneurs (microenterprises) to increase its business, after that their efforts would go more smoothly and more "big". Need funds for microenterprises after it got the support of capital will increase, so that the necessary Community financial institutions (micro) that can simultaneously serve their needs.

There are no other options for addressing the problem of poverty in Indonesia, the State must intervene. Purely market mechanisms will not be able to solve the problem of poverty. This intervention is the total intervention must involve all branches of Government: Executive, legislative and judicial. Even the fourth pillar of democracy i.e. the mass media must also be active control in poverty eradication efforts. The business world and society also need to participate,

\section{Conclusion}

As the basis for poverty eradication efforts, then the Government has to create growth. Without 
growth, no poverty eradication efforts might go well - just the same with the leveling of poverty. However, the sheer economic growth also is not enough. There must be economic growth can reduce unemployment and reduce the number of poor people. If there is growth, but the population remains poor, it is not the appropriate growth with desire together. To create a suitable growth this is State intervention is indispensable. Various initiatives are already underway in various groups in each scope should also remain ongoing.

The Government itself should run programs based on the four main goals of intervention as a cluster. Cluster one focusing on each household or individual - among other family Program Expectations; The second cluster of the target community or group. with the empowerment of communities - among other things through the national community empowerment Program Independently, here the community is empowered to correct fate independently, ranging from building roads, irrigation, up to the establishment of the mechanism of granting revolving capital; The third cluster focuses on the ability of the economy of the poor, including those who are slightly above the poor - among other things through the granting of Credit access and expansion of the Business of the people. Whereas the fourth cluster-based special targets, for example: fisherman, the poor of the city, or it could be the fulfillment of basic needs.

\section{Bibliography}

1) BPS. 1997; 2001. Statistik Indonesia. Badan Pusat Statistik, Jakarta

2) Bakry Aminuddin (2010), "Kebijakan Pendidikan Sebagai Kebijakan Publik", Jurnal MEDTEK, Volume 2, Nomor 1, April 2010.

3) Badan Pusat Statistik, 2003. Penduduk Miskin (PoorPopulation). Berita Resmi Statistis Penduduk Miskin No.04/Th.II/July, Jakarta:CBS.

4) Dasril, A.S. 1993. Pertumbuhan dan Perubahan Struktur Produksi Sektor Pertanan dalam Industrialisasi di Inonesia, 1971-1990. Disertasi Doktor, Program Pascasarjana, Institut Pertanian Bogor, Bogor.

5) Erwidodo. 1995. Transformasi Struktural dan Industrialisasi Pertanian di Indonesia. Pusat Penelitian Sosial Ekonomi Pertanian, Bogor.

6) Hayami, Y. dan V.W. Ruttan. 1991. Agricultural Development: An International Perspective. The Johns Hopkins University Press, Baltimore and London.

7) Iskandar, I. 1993. Transfromasi Perekonomian Sumatera Barat: Suatu Analisis Struktutal (1969-1990). Thesis, Pendidikan Pascasarjana KPK IPB-UNAND, Universitas Andalas, Padang.

8) JoAnn C. Carland dan James W. Carland (2004), "Economic Development: Changing the Policy to Support Entrepreneurship", Submitted to the Association for Small Business and Entrepreneurship, Western Carolina University 2004.

9) Jess Benhabib, Mark M. Spiegel (1994), "The role of human capital in economic development Evidence from aggregate cross-country data", Journal of Monetary Economics 34 (1994).
10) Kompasiana (2011), "Data Kemiskinan BPS Menampar Kebanggaan Sulawesi Selatan"

11) Kuswandi Aos (2005), "Kesiapan Aparat Pemerintah Dalam Pelaksanaan Otonomi Daerah Pada Bidang Pelayanan Masyarakat (Studi Tentang Implementasi UU No. 32/ 2004 Di Kota Bekasi)", Jurnal Madani Edisi I/Mei 2005.

12) Michael E. Porter (2000), "Location, Competition, and Economic Development: Local Clusters in a Global Economy", Economic Development Quarterly, Vol. 14 No. 1, February 2000 15-34.

13) Maskun, Sumitro, 1997 Pembangunan Masyarakat Desa, Asas, Kebijaksanaan, dan Manajemen, Media Widya Mandala, Yogyakarta,

14) Mariana Dede (2010), "Otonomi Daerah Dan Inovasi Kebijakan", governance, Vol. 1, No. 1, November 2010.

15) Maulida Elza Mutiara (2009), "Analisis Sektor Basis dan Potensi Daya Saing Pariwisata Kabupaten Tasikmalaya Pasca Otonomi Daerah", Departemen Ilmu Ekonomi Fakultas Ekonomi Dan Manajemen Institut Pertanian Bogor 2009.

16) Nasikun, 1995, Kemiskinan di Indonesia Menurun, dalam Perangkap Kemiskinan, Problem, dan Strategi Pengentasannya, (Bagong Suyanto, ed), Airlangga Univercity Press

17) Prof. Shailendrakumar Uttamrao Kale (2004), "Global Competitiveness: Role of Supply chain Management", Conference on Global Competition \& Competitiveness of Indian Corporate, IIMK 2004.

18) Rofiuddin Mohammad (2012), "Analisis Kinerja Keuangan Daerah di Pulau Madura Provinsi Jawa Timur Dalam Era Otonomi Daerah Tahun 2005-2009”, Jurnal Publikasi Fakultas Ekonomi Universitas Muhammadiyah Surakarta 2012.

19) Robert E. LUCAS, Jr. (1988), "On the Mechanics of Economic Development", Journal of Monetary Economics 22 (1988) 3-42. North-Holland.

20) Resya Nurul (2011), "Dasar, Pola dan Kebijakan Pembagunan Ekonomi”, resyapasha.blogspot.com/2011/04/dasar-pola-dan-kebijakanpembangunan.html.

21) Rudiyanto Dedi (2012), "Pengaruh Pengetahuan Dewan Tentanganggaran Terhadap Pengawasan Keuangan Daerah(APBD), Dengan Partisipasi Masyarakat dan Transparansi Kebijakan Publik Sebagai Variabel Moderating (Studi Empiris Pada Dprd Kabupaten Karanganyar)", Jurnal Publikasi Fakultas Ekonomi Universitas Muhammadiyah Surakarta 2012.

22) Septina Pipih (2008), "Faktor-Faktor Yang Mempengaruhi Kesenjangan Pembangunan Ekonomi Antar Daerah di Propinsi Jawa Barat Periode 1996-2006", Program Studi Ekonomi Pertanian dan Sumber Daya Fakultas Pertanian Institut Pertanian Bogor 2008.

23) Simatupang Pantjar (2011), “Analisis Kebijakan: Konsep Dasar Dan Prosedur Pelaksanaan (Policy Analysis: Basic Concept And Procedures)", Prosiding Seminar dan Ekspose Teknologi Hasil Pengkajian BPTP Jawa Timur ISBN 9793450-04-5.

24) Sukirno, S. 1985. Ekonomi Pembangunan: Proses, Masalah dan dasar Kebijaksanaan. Lembaga Penerbit Fakultas Ekonomi Universitas Indonesia, Jakarta.

25) Swasono dan Sulistyaningsih. 1993. Pengembangan Sumberdaya Manusia: Konsepsi Makro untuk Pelaksanaan di Indonesia. Izufa Gempita, Jakarta.

26) Thorvaldur Gylfason (2001), "Natural resources, education, and economic development", European Economic Review (2001).

27) Werimon Simson (2005), "Pengaruh Partisipasi Masyarakat dan Transparansi Kebijakan Publik Terhadap Hubungan Antara Pengetahuan Dewan Tentang Anggaran Dengan Pengawasan Keuangan Daerah (APBD) (Study Empiris Di 
Provinsi Papua)", Program Studi Magister Sains Akuntansi Program Pascasarjana Universitas Diponegoro November 2005.

28) Wahyuni Sri (2008), "Analisis Kemampuan Keuangan Daerah Pemerintah Kabupaten Sragen Dalam Mendukung Pelaksanaan Otonomi Daerah", Fakultas Ekonomi Universitas Muhammadiyah Surakarta 2008. 